DOI https://doi.org/10.18551/rjoas.2017-11.22

\title{
INNOVATIVE DEVELOPMENT AS THE FACTOR OF COMPETITIVENESS IN AGRO-INDUSTRIAL COMPLEXES OF CHINA AND RUSSIA
}

\author{
Li Long, Intern \\ Qingdao Haier Research and Develop Special Type Steel Plate Co., Ltd \\ Qingdao City, Shandong Province, China \\ E-mail: 346674967@qq.com
}

Krasova E.V., Candidate of Economic Sciences

Vladivostok State University of Economics and Service, Vladivostok, Russia

E-mail: elena krasova@rambler.ru

\begin{abstract}
Researching the problems of innovative development from the point of view of increasing the competitiveness of national agro-industrial complexes is the important sphere of world science, which considers the innovation factor as a basis for development of national economies. The main scientific and practical problem of the article is rather low degree of competitiveness of national agro-industrial complexes in China and Russia. These countries take many steps forward to develop the complexes now. The purpose of the article is consideration of innovative development as a factor of increasing the competitiveness of national agro-industrial complexes of China and Russia. The methodological basis of the study is the theses of modern theory of world economy, branch economy, the concept of innovative development, the theory of country's competitiveness. The article substantiates the actuality of innovation factor in development of the agro-industrial complex of any country, compares the agro-industrial sectors in Russia and China on the basis of a number of objective criteria. The article indicates such criteria as level of global competitiveness (general indicator), level of education of the population (general indicator), degree of modernization and labor productivity (for the agro-industrial complex), level of implementation of research and development (for the agro-industrial complex), level of patenting (for the agro-industrial complex).
\end{abstract}

\section{KEY WORDS}

Innovative development, agro-industrial complex, national economy, competitiveness, industrial modernization, labor productivity, agricultural machinery, R\&D in agro-industrial sector, new products in agricultural sector.

The competitiveness of national agro-industrial sector in modern economies is largely determined by achievements of scientific and technological progress, reflected in new technologies, equipment, knowledge and ways of organizing production. Traditional competitive advantages yield to more dynamic and knowledge-intensive advantages. Innovative potential of the agrarian industry acquires significance as one of the most important systemic factors of international competitiveness and economic growth of any country.

Transition to innovative development path is a key task of the investment policies in modern China and Russia. One of the priority problems is development of a new economy based on knowledge, which reflects the changing nature of development of the world economy from industrial to post-industrial [1]. Formation of a new economy can come to life due to a cardinal change of the economic structure in favor of high-tech industries, development of human capital, education sector, development of skills of personnel; transformation of the scientific and technical sphere in order to optimize its scope and structure, rise of the efficiency, and orientation on achieving concrete results. Development of knowledge economy is the basis for ensuring high, stable and high-quality economic growth in all sectors, including the agrarian industry [2]. 
During the research of innovation as a factor of competitiveness in the agro-industrial sector, the main task is to compare objectively development and effectiveness of the overall innovation potential of Russia and China. We can identify several key parameters: integrated indices of innovation development, assessment of contribution of the state and business companies to innovation and results obtained in the form of a certain technological level of industry. The first ones are generally accepted evaluation criteria. The second parameter is characterized by amounts of allocations of both public and private capital for research and development; number of scientific personnel in research institutions and enterprises; position of the infrastructure; as well as the educational level of population. The actual level of technological development of the agro-industrial complex can be judged by number of patents and licenses, volume of transactions for the purchase and sale of licenses and knowhow $[3,4]$.

\section{RESULTS AND DISCUSSION}

Researching the competitiveness of the agro-industrial sectors of China and Russia in the context of innovative activity, the following generally recognized evaluation criteria can be used: level of global competitiveness (general indicator); level of education of the population (general indicator); degree of modernization and labor productivity (for the agro-industrial complex); level of implementation of research and development (R\&D) (for the agro-industrial complex); level of patenting (for the agro-industrial complex).

1. Level of global competitiveness. This index is made from 12 terms of competitiveness, which detail the competitiveness of countries in the world at different levels of economic development. These terms are: "Quality of Institutions», "Infrastructure», «Macroeconomic stability», "Health and primary education», "Higher education and vocational training», "Efficiency of the market of goods and services», "Labor market efficiency», "Development of financial market», "Technological level», "The size of the internal market», "Competitiveness of companies» and «Innovation potential» [5]. Fragment of the global competitiveness rating 2015-2016 is presented in table 1.

Table 1 - Places of China and Russia in the rating of countries by the Index of global competitiveness, 2015/2016 [6]

\begin{tabular}{|c|c|c|}
\hline Rating & Country & The Index Value \\
\hline 1 & Switzerland & 5,7 \\
\hline 2 & Singapore & 5,6 \\
\hline 3 & USA & 5,5 \\
\hline 4 & Finland & 5,5 \\
\hline 5 & Germany & 5,5 \\
\hline 6 & Japan & 5,5 \\
\hline 7 & Hong Kong & 5,2 \\
\hline 15 & Canada & 5 \\
\hline 26 & South Korea & 4,9 \\
\hline 28 & China & 4,7 \\
\hline 30 & Iceland & 4,4 \\
\hline 50 & Kazakhstan & 4,4 \\
\hline 52 & Philippines & 4,4 \\
\hline 53 & Russia & 4,4 \\
\hline 56 & South Africa & 4,3 \\
\hline 57 & Brazil & \\
\hline
\end{tabular}

As we can see in this rating China is behind a number of developed countries - the United States, European countries. Russia is behind not only developed countries, such as Switzerland, Singapore, the United States, which are on the top, but also developing ones: China, which took $28^{\text {th }}$ place, Thailand ( $31^{\text {st }}$ place), Kazakhstan $\left(50^{\text {th }}\right.$ place). Analysis of changes in the Index of global competitiveness has proved that for Russia the average annual increase is 0.1 points. This growth rate is insufficient to enable the country to significantly improve its positions in the international rating in short period. 
Among 144 countries which were included in the global competitiveness rating in 2016, Russia ranks the $53^{\text {th }}$ place with 4.44 points from seven possible. The indicator of Russia's competitiveness has improved by 11 positions compared with 2013-2014, however, compared to 2008-2009 it is lower by 2 positions. Positive dynamics of Russia from 20122013 in the rating of global competitiveness is associated with high prices for energy products and is extremely unstable [7;8].

2. Level of education of population and development of the knowledge economy. According to forecast of experts from the Organization for Economic Cooperation and Development, the main driver of economic growth for the future up to 2060 will be the growth of labor productivity, that can be achieved largely due to investments to improving the quality of labor resources. This is especially true for Russia, India, Turkey, China, Brazil, and South Africa. According to the experts, average duration of schooling will increase over the next 50 years for two years, which means that human capital will grow, and will play more important role in macroeconomics than today.

Education level is calculated according to the United Nations Development Program Education Index, measuring the achievements of the state on two evaluation criteria: adult literacy and index of cumulative share of students receiving primary, secondary and high education [5]. Australia, New Zealand, Norway, Netherlands and the United States take the highest places in the Education Index. Russia has a modest $36^{\text {th }}$ place in this rating, and China took the distant $107^{\text {th }}$ place (table 2).

Table 2 - Places of China and Russia in the Education Index, 2016 [5]

\begin{tabular}{|c|c|c|}
\hline Rating & Country & The Index Value \\
\hline 1 & Australia & 0.927 \\
\hline 2 & New Zealand & 0.917 \\
\hline 3 & Norway & 0.910 \\
\hline 4 & Netherlands & 0.894 \\
\hline 5 & USA & 0.890 \\
\hline 10 & Czech Republic & 0.866 \\
\hline 36 & Russia & 0.780 \\
\hline 41 & Singapore & 0.768 \\
\hline 56 & Saudi Arabia & 0.723 \\
\hline 57 & Tonga & 0.720 \\
\hline 58 & Mauritius & 0.718 \\
\hline 106 & Philippines & 0.610 \\
\hline 107 & China & 0.610 \\
\hline 108 & Albania & 0.609 \\
\hline 184 & Chad & 0.256 \\
\hline 185 & Burkina Faso & 0.250 \\
\hline
\end{tabular}

Relatively low positions of Russia in the Education Index can be explained by Russia's transition to the European education system and lack of organizational efficiency of the process. Weak positions of China can be explained by large number of Chinese population, the incompleteness of construction of Chinese education' system, relatively low availability of higher education for a large cohort of rural population.

In the future, the most likely result of the transition to a new technological order will be the acceleration of economic growth rates, primarily in the industrially developed countries that have the highest scientific and technological potential. However, among leaders in development of new technologies may be countries from Southeast Asia, primarily China, which is cardinally increasing investment to research and development. For the period 19972007 such expenses increased in the country by an average of $22 \%$ per year, and in 20082013 - by $30 \%$ annually. As a result of the current decade, China has outrun Japan by the total expenditure on R\&D and since 2015 has firmly established itself in second place in the world after the United States, taking into account the purchasing power parities of the national currency [9].

3. Modernization and labor productivity. At present time in China and Russia investment growth has a great importance for ensuring sustainable development of the agro- 
industrial sector on the basis of modernization of production and increasing labor productivity. It is important for consolidation of China and Russia in five leading economies of the world, regardless of food and energy crises, which are becoming more and more global. It is necessary in the conditions of hardly predictable (even for short and medium periods) price dynamics on the world food market and agricultural raw materials, which largely determines the model of national economy.

Level and dynamics of modernization in Russian agro-industrial complex can be estimated by degree of technical equipment in agricultural enterprises (figure 1).

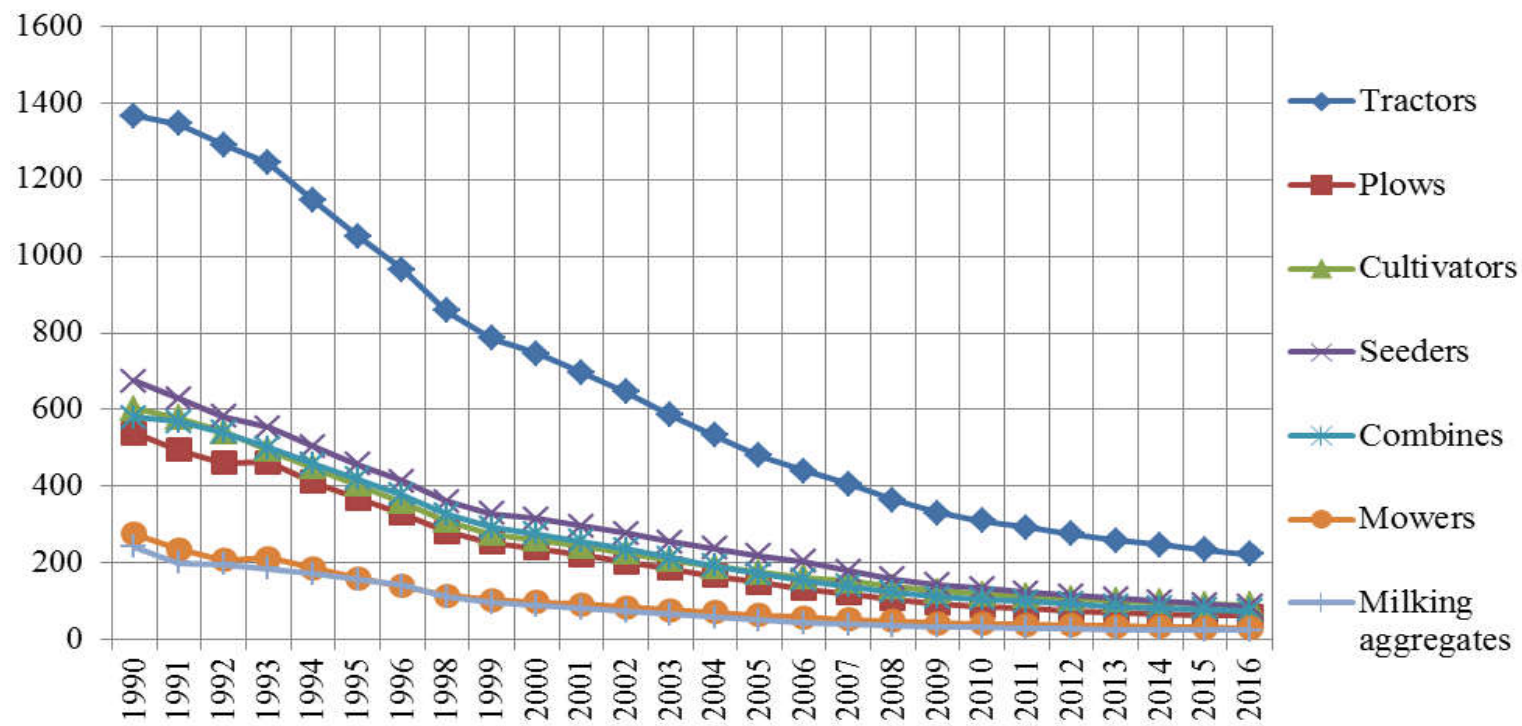

Figure 1 - Dynamics of park of main agricultural machinery in Russia for 1990-2016, thousand units [10]

As we can see, over the past 25 years in Russia, there has been a gradual but very significant reduction in technical park of agricultural machinery. At the same time, there is no full compensation by means of increase in labor productivity: the load of arable land per one tractor increased from 95 to 305 hectares, or by 3.2 times, per one combine harvester - from 152 to 425 hectares, or by 2.8 times, per one maize harvester - from 80 to 2497 hectares, or by 31.2 times [10].

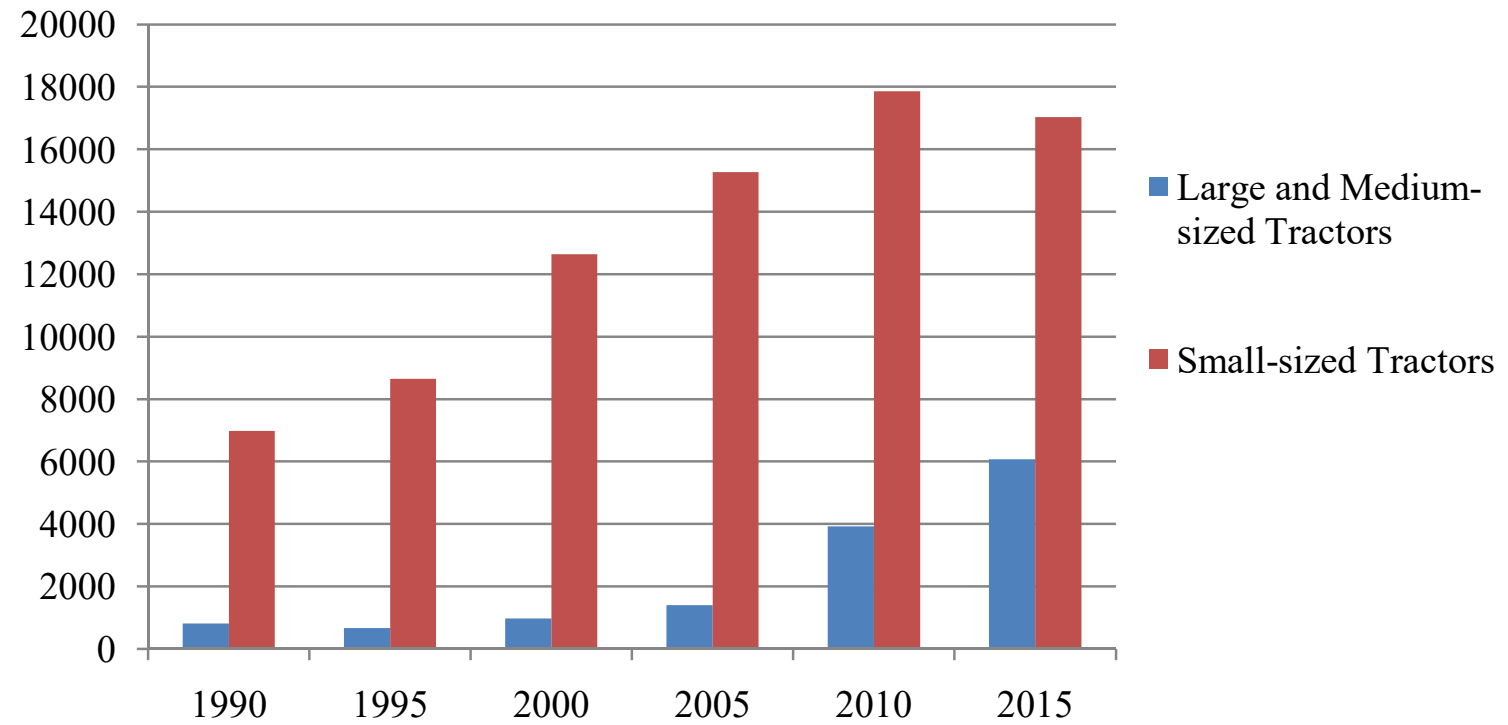

Figure 2 - Dynamics of tractors park in China for 1990-2015, thousand units [11] 
Chinese statistics show a significant increase in number of technical equipment in the agro-industrial sector: in particular, the number of tractors used in the fields of China has increased by 15 million units, or by 3 times (figure 2).

Similar dynamics can be seen in other types of agricultural machinery, as well as in the total capacity used in the fields of Russia.

4. Level of R\&D in industry. In Russia, during the years of reform, quality of science has significantly decreased. Costs of applied research have been reduced by three times, and in the agro-industrial sector - even more. Disintegration of the sphere of applied research was predetermined, in particular: the majority of scientific and production associations, sectoral scientific and technical complexes were eliminated, sectoral research institutes in agriculture were degraded. Also in connection with the reduction in funding, the scope of development suffered huge losses: the number of design bureaus, survey organizations, institutions of vegetable growing, rice growing and soybean, experimental stations of various agricultural purposes decreased. Fortunately, the least losses were borne by the sphere of fundamental agricultural research. Preservation of a significant part of potential of Russian fundamental research undoubtedly opens up prospects for the revival of national agro-industrial sector on the innovative basis.

In 2016, 3605 organizations carried out research and development in Russia, which is $10.1 \%$ (in developed countries about $30 \%$ ) of the total number of organizations. Total $35 \%$ of them are state-owned research organizations, $42 \%$ are organizations in business sector, $21 \%$ are institutions of higher professional education, $2 \%$ - nonprofit organizations [10]. Russia occupies low positions by such key indicator as the proportion of scientific researchers in the structure of the workforce, which is one of the main factors of the intellectual development of society. If in 2000 there were 78 scientific researchers per 10000 people in Russia, then in 2016 only 60. During this period, this indicator grew in Republic of Korea from 51 to 128, in Germany - from 65 to 85, in France - from 67 to 98 [12]. China shows high rates of growth in number of highly qualified personnel, increasing the share of scientific and practical-oriented workers trained abroad.

In China, 3650 organizations and institutions are currently engaged in scientific research and development. This number is rather comparable to the number in Russia. Among them, $20 \%$ of the institutions are subordinated to the central government, $80 \%$ - to local provincial governments [11]. The basic statistics of innovations in the agro-industrial sector of China can be seen in table 3 .

Table 3 - R\&D Activities and Patents of Industrial Enterprises in the Agricultural Sector of China [11]

\begin{tabular}{|c|c|c|c|c|}
\hline Sector of Manufacturing & $\begin{array}{c}\text { Full-time Equivalent of } \\
\text { R\&D Personnel (man- } \\
\text { year) }\end{array}$ & $\begin{array}{c}\text { Expenditure on } \\
\text { R\&D (ths yuan) }\end{array}$ & $\begin{array}{c}\text { R\&D } \\
\text { Projects } \\
\text { (unit) }\end{array}$ & $\begin{array}{c}\text { Number of Patent } \\
\text { Applications (piece) }\end{array}$ \\
\hline $\begin{array}{c}\text { Processing of Food from } \\
\text { Agricultural Products }\end{array}$ & 43933 & 216005 & 6750 & 9074 \\
\hline Manufacture of Foods & 31589 & 135429 & 4892 & 6677 \\
\hline $\begin{array}{c}\text { Manufacture of Liquor, } \\
\text { Beverages and Refined Tea }\end{array}$ & 20998 & 89997 & 3066 & 3610 \\
\hline Manufacture of Tobacco & 3878 & 20790 & 1301 & 3110 \\
\hline $\begin{array}{c}\text { Manufacture of Textile } \\
\begin{array}{c}\text { Fanufacture of Leather, Fur, } \\
\text { Feather and Related } \\
\text { Products }\end{array}\end{array}$ & 61758 & 207665 & 6918 & 17017 \\
\hline
\end{tabular}

Large amounts of labor, intellectual and financial costs are combined with their multiple growth over the past 20 years. At the same time, the agro-industrial sector occupies about $6.8 \%$ of labor costs in innovations, $7.2 \%$ in total costs for innovations, $8.0 \%$ in the number of R\&D projects and $7.0 \%$ in the total number of country patents.

China put forward a new slogan in reform of the system of science and technology named «Keep the main thing, release the rest». The words «keep the main thing» means adherence to the principle "better less, but better», according to which it is better to leave the best scientific and technical personnel of the fundamental science in the state sector, in 
research of high technologies, in solving key scientific and technical problems of the public values. They should make small, but selective forces for major breakthroughs. The words «release the rest» means realization of scientific and technical potential, transfer to market principles of self-financing, redistributing their personnel. They will be involved into enterprises in various forms or will form complexes of enterprises and organizations of scientific and technical profile. The goal of «keep the main thing» is to strengthen the scientific and technical power of the country and preserve the prospects for the future and requires raising the scientific and labor potential to a new level. The goal of «release the rest» is to mobilize the scientific and technical forces on a market basis in order to make a new contribution to economic construction, to maximize the advantages of competition in the science and technology achievements. "Keep the main thing, release the rest» means active integration of science and technology to production process, reflecting its role as a primary productive force $[13 ; 14]$.

5. Level of patenting. One of the most important indicators reflecting scientific and technical achievements in the country is the level of patenting. From 2003 to 2015 the number of patents received by Chinese specialists has grown more than by 12 times. China is the leader among the BRICS countries in the number of patents registered simultaneously in the United States, Western Europe and Japan. This impressive dynamics of growth in patent activity may indicate the preparation of China's technological expansion to the markets of developed countries.

In Russia, however, weak financial support, low level of material, technical and information support, as well as guarantees of the rights of inventors (including remuneration), and demand for research and development results are factors of low patent activity in Russia. In total, in 2015, Russian Federal Service for Intellectual Property, Patents and Trademarks got 64266 applications, which is by $7.5 \%$ less than in 2014. By number of applications of patents for inventions, Russia in 2015 was in the $7^{\text {th }}$ place in the world, significantly behind China (825139 units), the USA (571612 units) and Japan (328436 units) [15].

Table 4 - New Products Development and Production of Industrial Enterprises in the Agricultural Sector of China [11]

\begin{tabular}{|c|c|c|c|c|}
\hline Sector of Manufacturing & $\begin{array}{c}\text { New } \\
\text { Products } \\
\text { (unit) }\end{array}$ & $\begin{array}{c}\text { Expenditure on New } \\
\text { Products Development (ths } \\
\text { yuan) }\end{array}$ & $\begin{array}{c}\text { Sales Revenue } \\
\text { of New Products } \\
\text { (ths yuan) }\end{array}$ & $\begin{array}{c}\text { Export Revenue } \\
\text { of New Products } \\
\text { (ths yuan) }\end{array}$ \\
\hline $\begin{array}{c}\text { Processing of Food from } \\
\text { Agricultural Products }\end{array}$ & 7295 & 226197 & 2848430 & 129453 \\
\hline Manufacture of Foods & 5201 & 138230 & 1334518 & 108097 \\
\hline $\begin{array}{c}\text { Manufacture of Liquor, } \\
\text { Beverages and Refined } \\
\text { Tea }\end{array}$ & 2733 & 75036 & 1004757 & 42323 \\
\hline $\begin{array}{c}\text { Manufacture of Tobacco } \\
\text { Manufacture of Textile }\end{array}$ & 7466 & 15014 & 1650742 & 11398 \\
\hline $\begin{array}{c}\text { Manufacture of Leather, } \\
\text { Fur, Feather and Related }\end{array}$ & 2184 & 208141 & 4742104 & 598537 \\
\hline
\end{tabular}

In 2015, 34 thousand patents for inventions were issued in Russia (1.5 times more than in 2005). Generally 23.1 thousand were received by Russian applicants, and 10.9 patents by foreign applicants. At the same time the number of patent inventions in China in 2005-2015 increased more than 5 times. According to the number of issued patents for inventions, Russia in 2014 was in the $6^{\text {th }}$ place, behind the USA (277 835 units), Japan (277 079 units), China (207 688 units). 13000 patents were granted for utility models, and 3700 patents - for industrial designs. The coefficient of inventive activity (the number of Russian patent applications per 10000 people) was 1.65 in 2015 (in $2013-2.0$ ), and by 2020 it is projected to increase to 2.8 [15].

The main goal of active patent policy is to generate new scientific and technical ideas, which get the status of new business ideas then. Business ideas are transformed to new products. The number of new products in the agro-industrial sector of China is constantly 
increasing. Also all the indicators accompanying the release of new products are growing, which directly speaks about the increasing innovative activity of this country (table 4).

The agro-industrial sector occupies $7.9 \%$ of the total number of new products created in China, $7.0 \%$ - in total costs for creation of new products, $8.3 \%$ - in total revenue from sale of new products and $3.8 \%$ in export proceeds of new products.

In modern global world there is no state which can act in isolation in the process of researches and development. Trade relations in purchase and sale of licenses, patents, industrial designs and know-how have the great importance. Both China and Russia are involved in the international exchange of technology. In 2016 the share of volume of innovative goods, works and services in the total volume of shipped goods amounted $9.2 \%$ in Russia (in $2012-8 \%$ ), in China and the Republic of Korea - 27\%, France - 26\% , the USA $18 \%$, Japan $-17 \%$, Germany - 16\%. In the global export of high-tech products Russia occupies very modest positions. In 2015, the volume of Russian exports of high-tech products amounted to 8,656 million dollars, which is only $0.4 \%$ of the world exports. Russia is at the level of countries such as Brazil $(8,392)$, the Slovak Republic $(7,574)$, Denmark $(9,185)$, Israel $(9,635)$. Unfortunately, Russia is behind China conceding it 65 times, Germany (22 times), the United States (17 times), India (2 times) [12].

\section{CONCLUSION}

As a result of the research of innovative activity as a factor of competitiveness of the agro-industrial complexes of China and Russia, the following conclusions can be drawn.

1. By a number of criteria such as level of modernization and labor productivity, economic growth rates and the level of global competitiveness, China is one of the world's economical leaders, but by financial assets per capita and by level of education of population, it still behind many other countries. This lag is due to large population in the country and rather high level of poverty;

2. By a number of criteria such as level of modernization and labor productivity, the rate of economic growth and the level of global competitiveness, Russia lags far behind other countries. The main reason for this fact is the raw material orientation of the country's economy, low level of investment in the real sector of economy. By financial assets per capita, after several years of growth in 2015, Russia sharply deteriorated its position due to the fall in ruble's exchange rate and instability of the economy. By the level of education of the population, Russia keeps rather high level among world leaders, however, in recent years there has been a lag behind in this indicator.

\section{REFERENCES}

1. Ilchikov M.Z. (2015). Problems of innovative development of the Russian economy. Theoretical aspects: monograph. Moscow: Publ. house Knorus. -122 p.

2. Economics of the Agro-food market: the textbook (2014) / Edited by I.A. Minakova. Moscow: Publ. house INFRA-M. - 232 p.

3. Nechaev V.I., Birman V.F., Sandu I.S., Bershitsky Yu.I., Bogoviz A.V. (2012). Organization of innovative activities in the agro-industrial complex. Moscow: Publ. house Kolos. $-296 \mathrm{p}$.

4. Anokhina M.Y. (2015). Cluster technologies as a tool for agrarian regions development // Asian Social Science. T. 11. № 6. P. 261-271

5. World Economic Forum: Global Competitiveness Rating 2015-2016 // Information and Analytical Portal «Center for Humanitarian Technologies» [Electronic resource]. URL: http://gtmarket.ru/news/2016/09/30/7246

6. Official site of the Organization of Central Intelligence Agency [Electronic resource]. URL: https://www.cia.gov/library/publications/the-world-factbook/

7. Ivanova V.N., Seryogin S.N., Novoseltseva A.V. (2016). The open economy: priorities of development of agrarian and industrial complex for overcoming of external threats and modern challenges // Food Industry. № 1. P. 8-11 
8. Milner B.Z., Orlova T.M. (2015). Organization of innovation: horizontal communications and management: a monograph. Moscow: Publ. house INFRA-M. - 288 p.

9. World Economy. Statistics [Electronic resource] // Informational and analytical portal Ereport.Ru. URL: http://www.ereport.ru

10. Official site of the Federal State Statistics Service [Electronic resource]. URL: http://www.gks.ru/wps/wcm/connect/rosstat_main/rosstat/ru

11. Statistical Yearbook of China in 2016 [Electronic resource] // Official site of the National Bureau of Statistics of China. URL: http://www.stats.gov.cn/tjsj/ndsj/2016/indexeh.htm.

12. State Indicators [Electronic resource] // National Science Board. 2016. Arlington, VA: National Science Foundation Science and Engineering Indicators 2016 (NSB-2016-1), p. 4/45-46. URL: https://www.nsf.gov/statistics/2016/nsb20161/\#/stateind

13. The first meeting of the Presidium of the 16th Congress of the CPC. Report of Jiang Zemin at the 16th All-China Congress of the CPC (second part) // 20121108 人民日報 [People's Daily: PRC People's Daily]. November 08, 2012

14. Lee C. (2012). State regulation of the development of the agro-industrial complex in China // Business Inform. № 2. P. 122-125

15. Official site of the Federal Service for Intellectual Property, Patents and Trademarks (Rospatent) [Electronic resource]. URL: http://www1.fips.ru 